\title{
AND STEEL REINFORCEMENT
}

\author{
Prof V.GIRIDHAR
}

Professor, KSRM College of Engineering, Kadapa-Cell No: 9849499769

\section{ABSTRACT:}

This paper Emphasizes on flexural behavior of concrete with or without reinforcement. Bamboo is the world's fastest growing woody plant and it grows three times faster than most other species. To reduce the cost of construction, bamboo prefers to use as reinforcement in structural elements and studied its flexural behavior with bamboo and steel reinforcement and evaluate the strength parameters with steel reinforced beam and PCC specimens. Flexural strength of the concrete with bamboo reinforcement with respect to PCC is increased to $15.8 \%$ for 7 days and $30.34 \%$ for 28 days. Similar trends were observed in flexural strength of the concrete with steel reinforcement with respect to PCC is increased to $28.6 \%$ for 7 days and $77.7 \%$ for days.

Keywords: Bamboo reinforcement, Culm, Flexural strength, Steel Reinforcement and Workability

\section{INTRODUCTION}

Wide range usage of concrete is in infrastructural development because of its characteristics. The usage of available natural resources and the consequent energy requirement for this processing has a serious economic impact. For the past few years, several researchers found new materials for structural purpose in civil engineering construction. For this, many of them were chosen natural fiber utilization as reinforcement and it is being a convenient option over HYSD bars. In present state of study, both bamboo and steel are structural materials with different engineering properties. Due to the cost and availability of material, bamboo is used as alternative reinforcement in structural element. At present, bamboo is used in construction material because it is cheap and naturally available. In the present study, steel reinforcement is replaced by bamboo because of economical variation and plenty of quantity available in nature. The various constituents are presented in the bamboo culms, those are cellulose, hemi-cellulose and lignin, which occupy more than $90 \%$ of the total mass. Another reason for usage of bamboo in concrete making is consuming more than one ton of $\mathrm{CO}_{2}$ from the atmosphere. Currently the load carrying capacity of bamboo and steel reinforcement are being studied and compared the results with unreinforced specimens. Bamboo is readily used as a structural material in concrete elements [1]. Bamboo has both merits and demerits, good mechanical and energy consumption are come under the good properties and preservation and fire risks are under the category of bad [2]. Bamboo shows ductile behavior as in steel, hence it can be used and replaced steel as reinforcement in structural elements [3]. The mechanical properties of Bamboo has been varied with respect to the diameter, length, age, type, position of culms and moisture content [4]. Flexural strength of beam with bamboo reinforcement was practically $50 \%$ of the steel reinforced beam specimen [5]. Modulus of elasticity of bamboo was much lower than the steel, therefore deflection was higher in bamboo reinforced specimens [6]. The flexural strength of concrete beam with bamboo reinforcement is nearly double with respect to PCC specimens [7]. Bamboo has low modulus of elasticity and it can't be preventing the cracking of the concrete [8]. 
The tensile stress vs strain curve of the bamboo is linear up to failure. Bamboo average tensile strength is approximately $275 \mathrm{MPa}$ in the specimens without node and $100 \mathrm{MPa}$ in the specimens along with node [9]. The bond stress of concrete with bamboo and steel was studied and concluded as bond stress with bamboo was $50 \%$ of the concrete with deformed steel [10]. The bamboo reinforced slab and steel slabs had high tensile stress than plain slab specimens, their deflection of the specimens were nearly $40 \mathrm{KN}$ [11]. Bamboo has been used in various forms to determine its suitability as a construction material. For instance, the potential of bamboo as reinforcement in concrete was investigated [12]. It was observed that bamboo exhibits low modulus of elasticity than steel. So it doesn't avert cracks developed in concrete beneath final load [13]. The only difficulty with bamboo is subjected to fungal attack; hence before usage of this into the concrete composition, proper treatment to be needed like application of anti rusting elements.

\section{EXPERIMENTAL PROGRAMME}

Experimentation was performed to conclude following

* Mechanical Properties of constituent materials of concrete

* Feasibility study of bamboo as a material in structural element

* Flexural strength of concrete beam with steel and bamboo reinforcement

* Load vs Deflection behavior of concrete specimens with steel and bamboo reinforcement.

\section{MATERIALS}

\subsection{Cement}

Ordinary port land cement 53 grade confirming to IS12269 of BIRLA make was used in experimentation work. Specific gravity of cement was 3.13 and its consistency was $30 \%$. Initial setting time and final were $65 \mathrm{~min}$ and $270 \mathrm{~min}$.

\subsection{Fine aggregate}

Locally available "Penna River " sand was used in concrete composition, its specific gravity was 2.68 and confirming to Zone II of Table 4 of IS383-1970.

\subsection{Coarse aggregate}

Crushed granite aggregate available from local sources has been used. The size of coarse aggregate is $20 \mathrm{~mm}$ and $12.5 \mathrm{~mm}$.

Table 1: Properties of Coarse Aggregate

\begin{tabular}{|c|c|}
\hline Description & Value \\
\hline Specific gravity & \\
$20 \mathrm{~mm}$ & 2.60 \\
$12.5 \mathrm{~mm}$ & 2.56 \\
\hline Aggregate crushing value & $18.20 \%$ \\
\hline Water absorption & \\
$20 \mathrm{~mm}$ & $0.23 \%$ \\
$12.5 \mathrm{~mm}$ & $0.38 \%$ \\
\hline Impact value & \\
$20 \mathrm{~mm}$ & $20.2 \%$ \\
$12.5 \mathrm{~mm}$ & $22.42 \%$ \\
\hline
\end{tabular}

\subsection{Water}

Local available source of water used for mixing and curing of concrete and it is safe for usage into the structural elements because of lower chlorides, fluorides and total solids are within the limitations. 


\section{Table 2: Water Analysis}

\begin{tabular}{|l|l|l|}
\hline Parameter & Experimental values in mg/l & $\begin{array}{l}\text { Permissible limits of mixing of } \\
\text { water to the concrete in mg/l }\end{array}$ \\
\hline PH & 7.5 & $6-8$ \\
\hline Taste & Agreeable & Normal \\
\hline Acidity & 10 & 50 \\
\hline Alkalinity & 88 & 250 \\
\hline Chlorides & 300 & 2000 for PCC \\
& & 3000 for RCC \\
\hline Total Hardness & 230 & 300 \\
\hline Sulphates & 90 & 150 \\
\hline Fluorides & 0.60 & 1.5 \\
\hline Dissolved Oxygen & 6 & $5-7$ \\
\hline Total solids & 120 & 500 \\
\hline Total dissolved solids & 150 & 500 \\
\hline Total suspended solids. & 100 & 300 \\
\hline
\end{tabular}

\subsection{Bamboo Reinforcement}

It is considered a composite material because it consists of cellulose fibers imbedded in a lignin matrix. Cellulose fibers are aligned along the length of the bamboo providing maximum flexural strength and rigidity in that direction. Based on the previous study, following properties are listed below. Average size of the bamboo reinforcement was 12 to $14 \mathrm{~mm}$ into the beam elements. Fig 1 and 2 shows the fabricated beam elements with bamboo and steel. Fig1 and 2 shows the beam reinforcement with bamboo and steel

* Specific gravity -0.575 to $0.655 \mathrm{gr} / \mathrm{cc}$

* Average weight - $0.625 \mathrm{~kg} / \mathrm{m}$

* Modulus of rupture - 610 to $1600 \mathrm{~kg} / \mathrm{cm}^{2}$

- Modulus of Elasticity - 1.5 to $2.0 \times 10^{5} \mathrm{~kg} / \mathrm{cm}^{2}$

* Ultimate compressive stress- 794 to $864 \mathrm{~kg} / \mathrm{cm}^{2}$

- Safe working stress in compression $-105 \mathrm{~kg} / \mathrm{cm}^{2}$

- Safe working stress in tension - 160 to $350 \mathrm{~kg} / \mathrm{cm}^{2}$

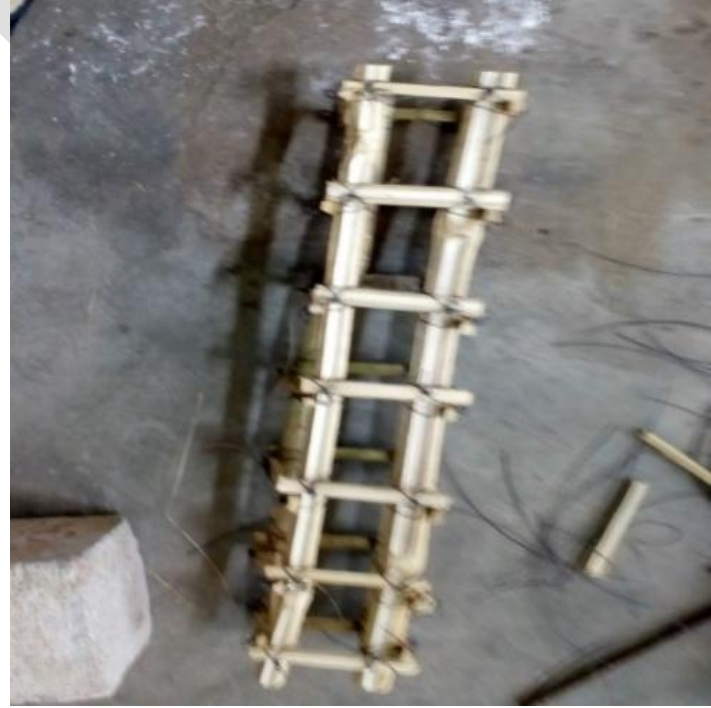

Fig 1: Bamboo reinforcement

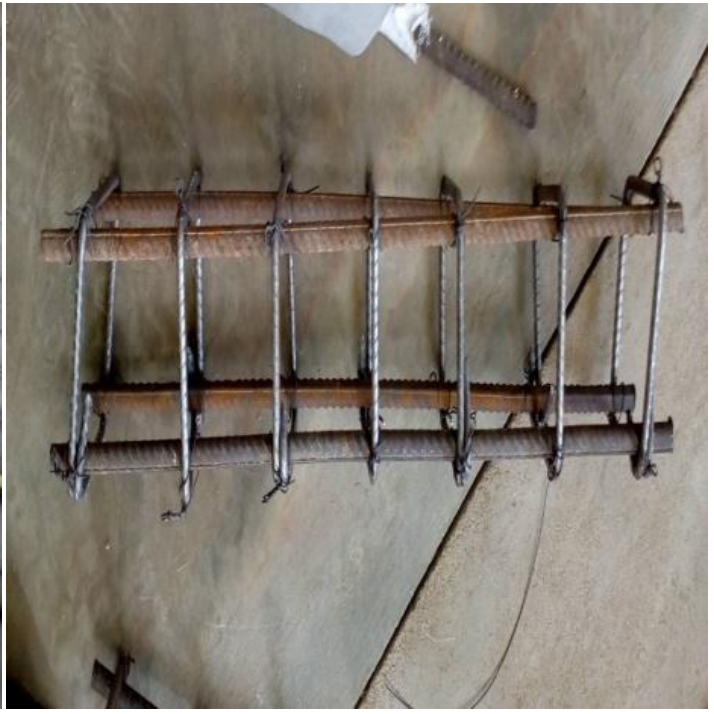

Fig 2: Steel Reinforcement 


\subsection{Steel reinforcement}

$12 \mathrm{~mm}$ and $8 \mathrm{~mm}$ diameter HYSD bars were used as reinforcement in concrete beams. 12 $\mathrm{mm}$ bars were used as main reinforcement and for stirrups $8 \mathrm{~mm}$ bars were used.

Table 3: Properties of Steel

\begin{tabular}{|l|l|l|}
\hline \multirow{2}{*}{ Description } & Value \\
\cline { 2 - 3 } & Sample 20mm & Sample 12.5 mm \\
\hline Elongation Length & $70 \%$ & $60 \%$ \\
\hline Reduction Area & $70.41 \%$ & $67.0 \%$ \\
\hline Yield Strength & $629.46 \mathrm{~N} / \mathrm{mm}^{2}$ & $617.26 \mathrm{~N} / \mathrm{mm}^{2}$ \\
\hline Ultimate Strength & $733.26 \mathrm{~N} / \mathrm{mm}^{2}$ & $721.94 \mathrm{~N} / \mathrm{mm}^{2}$ \\
\hline Breaking Strength & $544.13 \mathrm{~N} / \mathrm{mm}^{2}$ & $522.91 \mathrm{~N} / \mathrm{mm}^{2}$ \\
\hline
\end{tabular}

\section{MIXING AND CASTING}

M20 grade nominal mix proportion was chosen for casting of concrete beam specimens. To resolve the flexural strength of concrete, it is essential to cast beam specimen and evaluate at which load concrete beam specimen will fail. The size of the specimen was 700x150x150 mm used in experimental work. Modulus of flexure test has been performed under symmetrical third point loading pattern. Determination of flexural strength is an essential to estimate load at which concrete specimen will split into pieces.

A total of 18 specimens were cast in steel moulds of size150x150x700mm. Among these, 6 specimens were cast without reinforcement as PCC specimens. Another 6 specimens were cast with steel reinforcement and rest of the specimens with bamboo reinforcement. Fig 3 and 4 are representing steel moulds and casting of specimens after manual vibration.

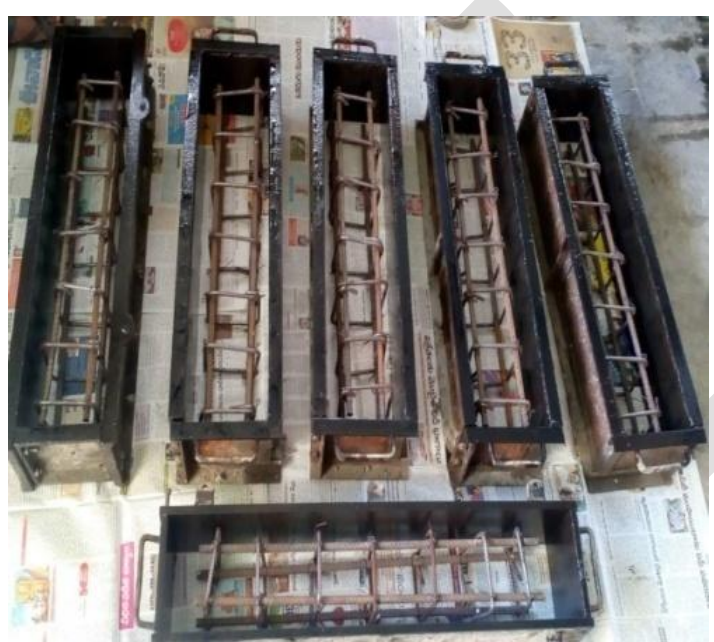

Fig 3: Steel mould with reinforcement

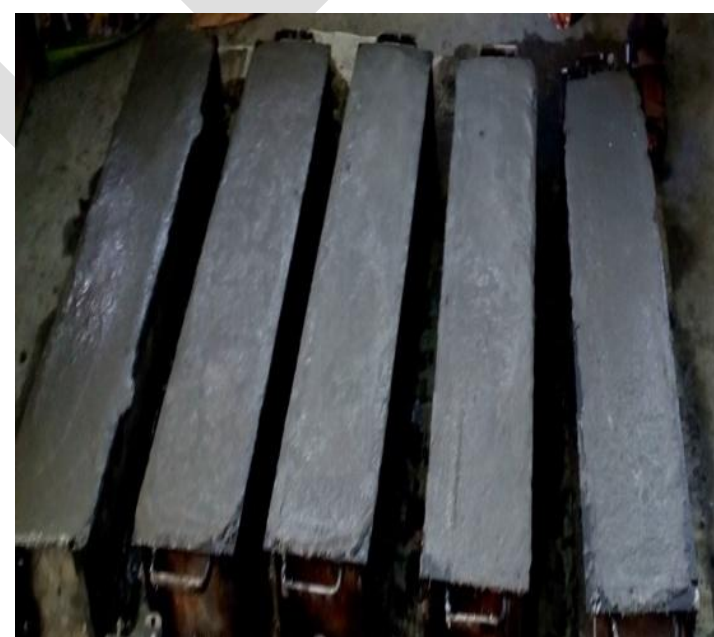

Fig 4: Beam specimens after casting

For evaluating the flexural strength, a concrete beam was subjected to flexure using symmetrical third point loading until failure occurs according to the ASTM C 78-02. The modulus of rupture is determined from the moment at failure. Flexural strength of the beam specimen is calculated according to IS516-1959.

Flexural strength $=3 \mathrm{~Pa} / \mathrm{bd}^{2}$

$$
\text { When ' } \mathrm{a} \text { ' }<13.3 \mathrm{~cm} \text { and }>11 \mathrm{~cm}
$$

\section{TEST PROCEDURE}

The load points were marked at one third of the span and the theoretical maximum tensile stresses reached at bottom fiber of the test beam, known as the Modulus of rupture. Under third-point loading, one-third the length of the extreme fiber in the beam was subjected to the maximum 
stresses, so that the critical crack developed at any section in one-third of the beam length. The probability of a weak element (of any specified strength) being subjected to the critical stress is considerably greater under third-point loading than when a central load acts, the centre-point loading test will give a higher value of modulus of rupture and more variable values. In consequence of this, centre-point loading test is very rarely used in resolving the flexural strength. Test set up of third point loading specimen is represented in Fig 5.

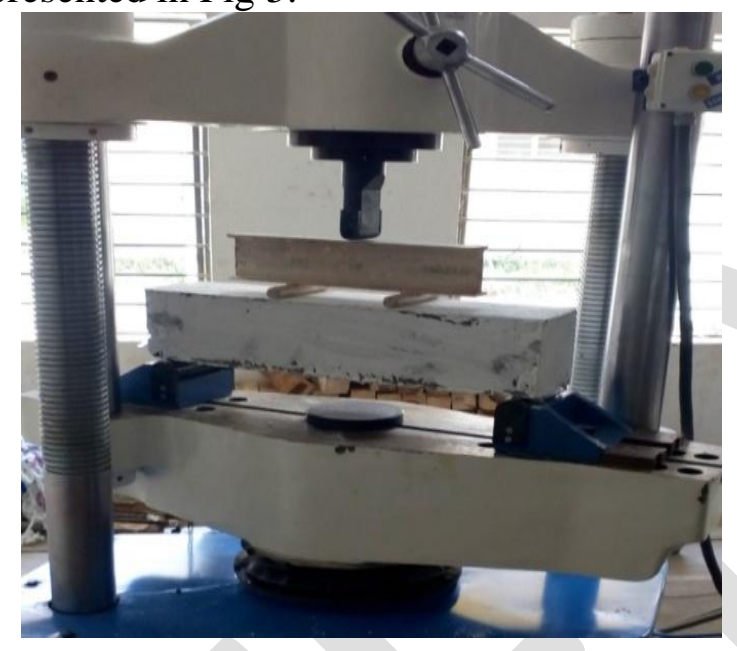

Fig 5 Third point loading arrangement

\section{RESULTS AND DISCUSSIONS}

\subsection{Workability}

Workability of concrete was studied by the slum values and compaction factor tests, these values are presented in Table No 4. The average value of slump was $15.5 \mathrm{~cm}$ for and CF was more than 0.86 , hence these values show the workability condition.

Table No 4: Test results for the slump values for beams

\subsection{Flexural strength of beam specimens}

\begin{tabular}{|l|l|l|}
\hline Different samples & $\begin{array}{l}\text { Slump Value } \\
\text { in cm }\end{array}$ & $\begin{array}{l}\text { Compaction } \\
\text { Factor Value }\end{array}$ \\
\hline Bamboo samples & 16.5 & 0.88 \\
\hline Steel samples & 14.5 & 0.85 \\
\hline
\end{tabular}

Sudden failure of PCC specimens was observed during the performance of test, but specimens with steel and bamboo reinforcement cannot fails suddenly due to the presence of reinforcement. Reinforcement is restraining the sudden failure because steel has high modulus of elasticity and bomaboo has lower modulus of elasticity than steel. Flexural strength of the beams are tabulated in Table No 6

Table No 5.1: Flexural Strength of PCC beams

\begin{tabular}{|l|l|l|l|l|}
\hline S.No & $\begin{array}{l}\text { Weight of the beam } \\
\text { (Kg) }\end{array}$ & $\begin{array}{l}\text { Curing Period } \\
\text { (Days) }\end{array}$ & $\begin{array}{l}\text { Flexural Strength } \\
\text { MPa }\end{array}$ & $\begin{array}{l}\text { Average Flexural } \\
\text { strength MPa }\end{array}$ \\
\hline 1 & 42.4 & \multirow{2}{*}{7} & 7.47 & \\
\hline 2 & 43.6 & & 7.11 & 7.66 \\
\hline 3 & 40.0 & \multirow{3}{*}{28} & 7.4 & \\
\hline 4 & 40.0 & & 8.82 & 8.75 \\
\hline 5 & 40.5 & & 9.59 & \\
\hline 6 & 41.0 & & & \\
\cline { 5 - 6 } & &
\end{tabular}




\section{Table No 5.2: Flexural Strength of Bamboo RCC beams}

\begin{tabular}{|c|c|c|c|c|}
\hline S. No & $\begin{array}{l}\text { Weight of the beam } \\
\text { (Kg) }\end{array}$ & $\begin{array}{l}\text { Curing } \\
\text { Period } \\
\text { (Days) }\end{array}$ & $\begin{array}{l}\text { Flexural } \\
\text { Strength } \mathbf{N} / \mathbf{m m}^{2}\end{array}$ & $\begin{array}{l}\text { Average } \\
\text { Flexural } \\
\text { strength MPa }\end{array}$ \\
\hline 1 & 39.0 & \multirow{3}{*}{ (Dayo) } & 7.21 & \\
\hline 2 & 38.0 & & 9.13 & 8.54 \\
\hline 3 & 40.0 & & 9.28 & \\
\hline 4 & 42.0 & \multirow{3}{*}{28} & 10.48 & \\
\hline 5 & 39.0 & & 10.13 & 10.91 \\
\hline 6 & 40.0 & & 12.13 & \\
\hline
\end{tabular}

As per the above test results, average 7 days strength of PCC, BRCC and SRCC are 7.66, 8.54 Mpa and $11.18 \mathrm{Mpa}$. 7 days Strength of the concrete is being increases to $11.49 \%$ and $45.95 \%$. Average 28 days flexural strength of PCC, BRCC and SRCC are 8.75, 10.91 and $14.82 \mathrm{MPa} .28$ days Strength of the concrete is being increases to $24.69 \%$ and $69.37 \%$. The increase of flexural strength is due to the ductility and malleability of steel and bamboo reinforcement. The elastic modulus of bamboo is smaller than the steel that why 28 days strength deviated from 10.91 to $14.82 \mathrm{MPa}$. Flexural strength is also influenced by the absorption capacity of bamboo reinforcement. It is concluded that flexural strength of the bamboo reinforcement is $73 \%$ of the steel reinforcement. Comparison 7 days and 28 days strength are shown in fig 6 and 7.

Table No 5.3: Flexural Strength of Steel RCC beams

\begin{tabular}{|c|c|c|c|c|}
\hline S. No & $\begin{array}{l}\text { Weight of the beam } \\
\text { (Kg) }\end{array}$ & $\begin{array}{l}\text { Curing Period } \\
\text { (Days) }\end{array}$ & $\begin{array}{l}\text { Flexural Strength } \\
\mathrm{N} / \mathrm{mm}^{2}\end{array}$ & $\begin{array}{l}\text { Average } \\
\text { Flexural } \\
\text { strength MPa }\end{array}$ \\
\hline 1 & 40.0 & \multirow{3}{*}{7} & 11.6 & \\
\hline 2 & 42.0 & & 10.22 & 11.18 \\
\hline 3 & 43.0 & & 11.73 & \\
\hline 4 & 43.5 & \multirow{3}{*}{28} & 14.08 & \\
\hline 5 & 44.0 & & 15.36 & 14.82 \\
\hline 6 & 42.0 & & 15.02 & \\
\hline
\end{tabular}

Table 5.4: Average Flexural strength of different specimens

\begin{tabular}{|l|l|l|l|l|l|}
\hline S.No & Type of Sample & $\begin{array}{l}7 \quad \text { Days } \\
\text { Average } \\
\text { Flexural } \\
\text { strength } \\
\text { in Mpa }\end{array}$ & $\begin{array}{l}\text { 28 Days } \\
\text { Average } \\
\text { Flexural } \\
\text { strength } \\
\text { in Mpa }\end{array}$ & $\begin{array}{l}\text { Percentage } \\
\text { variation of 7 } \\
\text { days flexural } \\
\text { strength }\end{array}$ & $\begin{array}{l}\text { Percentage } \\
\text { variation } \\
\text { of 28 days } \\
\text { flexural } \\
\text { strength }\end{array}$ \\
\hline 1 & PCC & 7.66 & 8.75 & -- & -- \\
\hline 2 & $\begin{array}{l}\text { Bamboo Reinforced } \\
\text { samples }\end{array}$ & $\mathbf{8 . 5 4}$ & 10.91 & 11.49 & 24.69 \\
\hline 3 & $\begin{array}{l}\text { Steel Reinforced } \\
\text { Samples }\end{array}$ & 11.18 & 14.82 & 45.95 & 69.37 \\
\hline
\end{tabular}



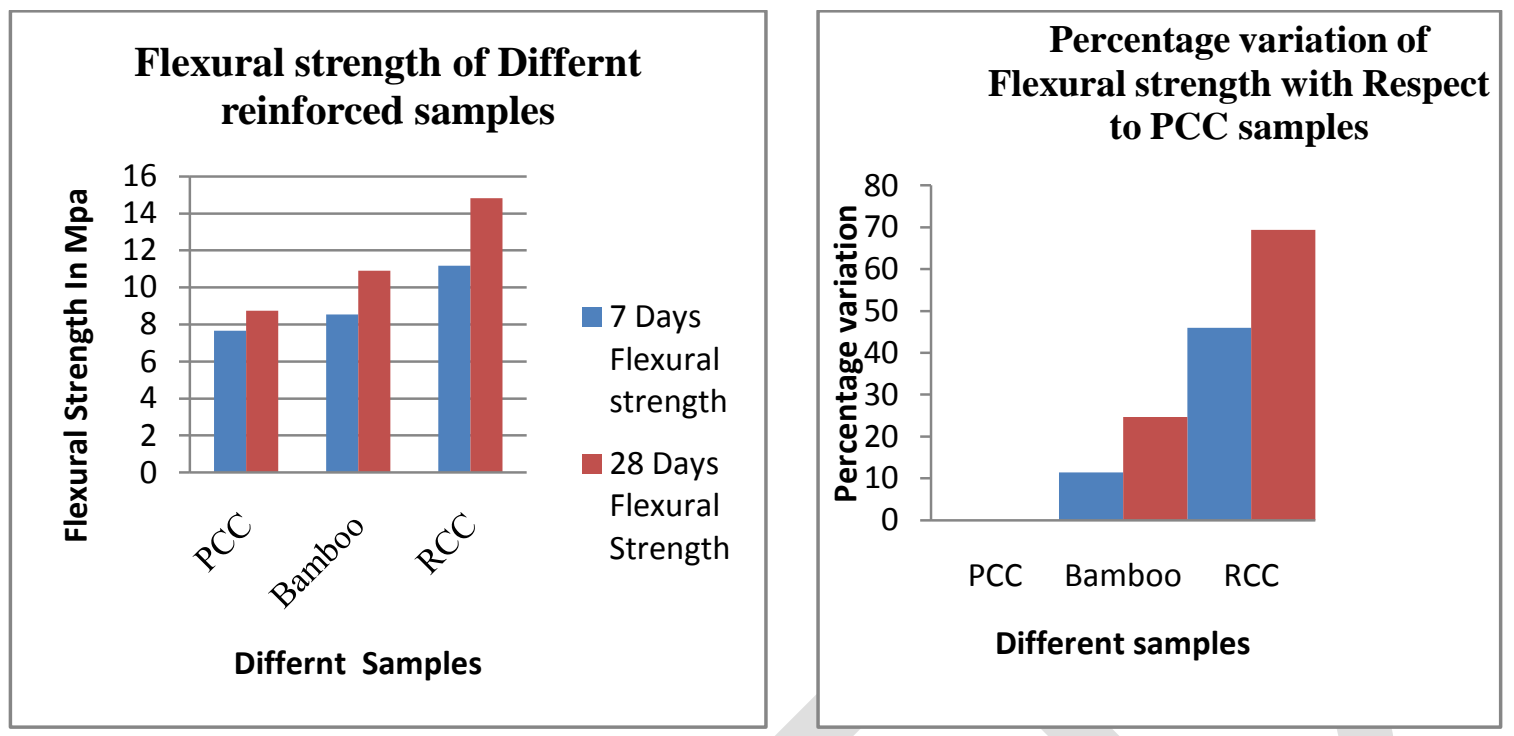

Fig6 Flexural strength of Different specimens Fig 7 Percentage variation of flexural strength

\section{CONCLUSIONS}

Based on the experimental Results following results are drawn

* Based on the physical and mechanical properties, bamboo is a useful structural material

* Water absorption of bamboo is higher, hence epoxy coating is applied on surface .

* Flexural strength of the bamboo specimens are $11.49 \%$ and $24.69 \%$ more than the Plain cement concrete specimens

* During the testing, sudden failure observed in PCC specimens but for bamboo is restrain for sudden failure because of elasticity modulus of bamboo.

* Finally concluded as bamboo shall use as a reinforcement in beams, columns and stirrups in structural elements.

\section{REFERENCES}

[1] Ghavami, K, "Bamboo as reinforcement in structural concrete elements". Cement \& Concrete Composites 27, (2005) 637-649.

[2] International network for Bamboo and Rattan (INBAR2002), a project on Bamboo structures at the Technical University of Eindhoven.

[3] Ajinkya Kaware, U.R. Awari and M.R.Wakchaure, "Review of Bamboo as reinforcement material in concrete structure", International journal of Innovative Research in Science, Engineering and Technology, Vol-2, Issue-6, June 2013, pp 2461-2464.

[4] Lo TY, Cui HZ and Lueng HC, "The Effect of Fiber Density on Strength Capacity of Bamboo", Journal of Materials Letter, Vol-58, pp 2595-2598, 2004.

[5]. IK Khan, "Performance of Bamboo Reinforced Concrete Beam", International Journal of Science, Environment and Technology, Vol-3, No-3, pp 836-840, 2014.

[6] Md Ahsan Sabbir, S.M.Ashafaqul Hoq and Saiada Faudi Fancy, "Determination of Tensile Property of Bamboo for Using as Potential Reinforcement in the Concrete", International Journal of Civil and Environmental Engineering IJCEE-IJENS, Vol-11, No-5, pp47-51, Oct2011.

[7] Dr Shakeel Ahmad, Altamash Raza and Hinagupta, "Mechanical properties of Ba,boo Fibre reinforced concrete", $2^{\text {nd }}$ International conference on Research in science, Engineering and Technology(ICRSET-2014), March 21-22,Dubai. 
[8] M. M. Rahman, M. H. Rashid, M. A. Hossain, M. T. Hasan and M. K. Hasan, Performance Evaluation of Bamboo Reinforced Concrete Beam, International Journal of Engineering \& Technology IJET-IJENS Vol: 11 No: 04, 2011.

[9] Humberto C. Lima Jr. , Fabio L. Willrich, Normando P. Barbosa, Maxer A. Rosa, Bruna S. Cunha, “ Durability Analysis of Bamboo as Reinforcement" Materials and Structure (2008) 41: 981-989.

[10] Masakazu TERAI and Koichi MINAMI, "Research and Development of Bamboo Reinforced Concrete Structure", in 15 WCEE, 2012.

[11] MaruthupandianG, Saravanan.R, Suresh Kumar.S and Sivakumar.B.G, “ Astudy on Bamboo Reinforced Concrete Slabs", Journal of chemical and pharmaceutical sciences, Vol-9, Issue 2, pp 988-980, 2016.

[12] M. Adom-Asamoah and O. R. Afrifa, "A comparative study of bamboo reinforced concrete beams using different stirrup materials for rural construction," International Journal of Civil and Structural Engineering, vol. 2, no. 1, pp. 407-423, 2011.

[13] Syed Faraz Siddique, Priyanka S and Nishanth L, "Behavior of Reinforced Cement Concrete Beam with Bamboo as Partial Replacement for Reinforcement", International Journal of Civil Engineering and Technology (IJCIET) Volume 8, Issue 9, September 2017, pp. 580-587.

\section{AUTHORS INFORMATION}

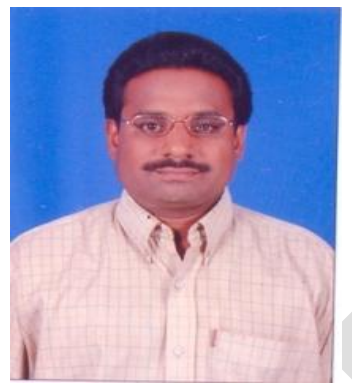

Prof V.Giridhar completed his post graduation in structural Engineering from JNTUH-Hyd and acquired doctorial degree from JNTUA-Ananthapuramu. He has wide experience in research on effective utilization of waste materials in concrete composition, high performance and high strength concretes. He published 15 research articles in international journals and 3 international conferences. He published a book in international publisher. Presently working as professor of Civil Engineering department at KSRM College of Engineering-Kadapa, 